\title{
Media Representations of Religion, Spirituality and Non-Religion in Australia
}

\author{
Enqi Weng *(D) and Anna Halafoff $($ ) \\ Faculty of Arts and Education, Deakin University, Melbourne, VIC 3125, Australia; anna.halafoff@deakin.edu.au \\ * Correspondence: enqi.weng@deakin.edu.au
}

Received: 28 May 2020; Accepted: 29 June 2020; Published: 3 July 2020

\begin{abstract}
Despite predictions of decline, religion has featured prominently in the public sphere and the media since the events of 11 September 2001. Previous research on media and religion in Australia post-September 11 has focused largely on its negative impacts, particularly on Muslim communities. This article, in contrast, examines media representations of religion, spirituality and non-religion on an 'ordinary day', of 17 September, over a three-year period in the city of Melbourne. Its findings reveal that religion, in its myriad forms, permeates many aspects of Australian public life, but in ways which do not always reflect the actual religious composition and lived experiences of worldview diversity in Australia.
\end{abstract}

Keywords: religious diversity; spirituality; non-religion; worldview diversity; mediatisation of religion; media and religion

\section{Introduction}

Since the events of 11 September 2001, reporting on religion, and particularly on Islam, has gained new prominence in the media, globally and within Australia, despite the assertion of the secularisation thesis that it would fade from social and public significance (Hjelm 2015; Bouma et al. 2007). Previous research has documented the role of the media in contributing to negative prejudices against Muslims, and in sensationalising religion since 2001. Moreover, recent research on religion in Australian media discourses has found that it tends to be presented primarily through dominant and narrow perspectives, frequently disconnected from everyday religious experiences (Bouma et al. 2007; Weng 2019, 2020). This has highlighted the need for more educational programs focused on religious literacy, that include learning about diverse religions and worldviews and of their presence in society, in order to advance greater levels of understanding and respect for them (Halafoff et al. 2019a, 2019b) and a need for journalists and journalism students to be better equipped in sensitively handling news reporting on religion (Weng 2020). Scholars have also argued that both media reporting and educational initiatives must better match the lived and complex non-religious, religious, and spiritual diversity of Australian society (Halafoff et al. 2020; Weng 2019, 2020).

This article presents the Australian findings of a larger study, 'Religion on an Ordinary Day,' that was conducted as part of the 'Religion, Discourse and Diversity Project', co-led by Kim Knott (Lancaster University) and Lori Beaman (University of Ottawa), within the broader 'Religion and Diversity Project' led by Beaman. It included case studies from Canada, the United Kingdom, Finland and Australia. ${ }^{1}$ This paper focuses on newspaper coverage of religion in the city of Melbourne,

1 The 'Religion on an Ordinary Day' project was co-funded by the UK's Economic and Social Research Council (which funded the 'Religion, Discourse and Diversity Project') and the Canadian Social Sciences and Humanities Research Council (which funded the 'Religion and Diversity Project'). 
the capital city of the Australian state of Victoria, on the 'ordinary day' of 17 September, over three years, in 2013, 2014, and 2015. ${ }^{2}$ This ordinary day of 17 September was randomly selected by the international research team, so as to capture how religion was depicted in everyday media, in contrast to an anniversary of a major event, such as of 11 September 2001.

The Melbourne quantitative and qualitative findings are being compared to those in the other countries, in a forthcoming edited collection arising from this project, but this paper presents and interrogates the Australian qualitative, thematic data in far more detail. The analysis of the Melbourne data shows that the ways that religion, spirituality and non-religion manifest in public life do not always reflect the religious composition and lived experiences of worldview diversity in Victoria and Australia. ${ }^{3}$

\section{Religious Diversity in Australia}

Australia is a religiously diverse society, and this diversity long predates white settlement. Indigenous Australians have diverse cultural and spiritual practices. Waves of immigrants from Asia have long brought Taoism, Confucianism, Buddhism, Hinduism, Sikhism and Islam to Australia, since the 1850s Gold Rush. The Australian Immigration Restriction Act, widely known as the 'White Australia Policy', was implemented in 1901 until 1973, largely to stem the flows of migration from Asia, and resulted in the myth of a white Christian Australia (Bouma and Halafoff 2017). Multiculturalism was embraced in the 1970s and remains a central part of the state of Victoria's identity, yet it has eroded in part, with a swing toward a more narrow nationalism and accompanying policies of social cohesion and citizenship, emerging at the federal level, that have also impacted Victoria's policies in more recent years (see (Ezzy et al. 2020) in this Special Issue).

In terms of religious demographics, the state of Victoria follows a similar pattern to the rest of Australia and many Western societies in that it is becoming increasingly non-religious and religiously diverse concurrently. In the 2011 Census, $57.5 \%$ of Victoria's population identified as Christian, $24 \%$ as having No Religion, $3.1 \%$ as Buddhists, $2.9 \%$ as Muslims, $1.6 \%$ as Hindus, and $0.8 \%$ as Jews. In the 2016 Census, $47.9 \%$ of Victoria's population identified as Christian, $31.9 \%$ as having No Religion, $3.3 \%$ as Muslims, $3.1 \%$ as Buddhists, $2.3 \%$ as Hindus, and $0.7 \%$ as Jews. The fastest growing groups are Hindus, Muslims, and No Religion. Christianity, by contrast, is declining sharply (.idcommunity n.d.).

Interest in spirituality is also strong in Australia. The Australian National Church Life Survey Research Australian Community Survey, a national random survey of 1258 Australian adults (over 18) conducted in December 2016, found $39.9 \%$ to be 'Nones', $16.9 \%$ to be 'Spiritual but not Religious,' and $43.3 \%$ to be 'Religious and Spiritual' (Pepper and Powell 2016). The Australia's Generation Z (AGZ) study, conducted in 2016-2018, found six types of worldviews among 13-18 year-olds: $23 \%$ were 'this-worldly'/non-religious, $15 \%$ were 'indifferent', $18 \%$ were 'spiritual but not religious', $8 \%$ were 'religious and spiritual', 20\% were 'nominally religious' and 17\% were 'religiously committed' (Singleton et al. 2019). The AGZ study also found that a large number of Australian teens engaged in spiritual practices and beliefs; $22 \%$ had practiced yoga and 30\% had practiced meditation (both outside of school), 20\% believed in astrology, 30\% in reincarnation, and 50\% in karma (Singleton et al. 2019).

Australia has no state church, and Australians have been described as being quite private and subdued in their religious expression, with religious participation recorded as low to moderate (Bouma 2006). This has been changing in recent years, with more public displays of conservative religiosity by political figures, including current and recent Prime Ministers Scott Morrison and Tony Abbott, and in vehement debates regarding same-sex marriage and religious freedom. Disturbingly, the frequency of incidents of 'discrimination on the basis of skin colour, ethnicity or religion' reported

2 The authors of this article intend to repeat this coding process and data analysis in Melbourne on 17 September 2020, and subsequently every five years.

3 We acknowledge Professor Peter Horsfield's contribution to this research project, particularly in the extensive discussion of the emerging main themes, and in earlier coding and quantitative analysis of the Melbourne findings. 
by respondents in the annual Australian Mapping Social Cohesion studies increased from $9 \%$ in 2007 to 20\% in 2017, with Muslims and Hindus reporting the highest levels of such incidents committed against them. In addition, since 2010, 22-25\% of respondents have noted 'very negative' or 'negative' attitudes towards Muslims, compared to 4-5\% toward Christians and Buddhists (Markus 2017, pp. 3, 57, 59).

The Australia's Generation Z study also found that $25 \%$ of young Australians had less-than-positive views about Muslims, and more optimistically, that students who had participated in educational programs about diverse religions and worldviews had more positive opinions toward religious minorities, and most notably towards Muslims and Hindus (Singleton et al. 2019). This study, however, noted that there was only a moderate level of religious literacy among Australian teens and that while it was broad, it was shallow. The researchers also concluded, drawing on Meredith McGuire (2008) work on 'lived religion' and Inger Furseth (2018) work on 'religious complexity', that educational programs needed to better reflect the lived and complex reality of non-religious, religious and spiritual diversity of Australian teens, as existing programs tended to preference the Abrahamic religions of Christianity, Islam and Judaism, and other major faith and no-faith traditions only (Halafoff et al. 2019b, 2020; Victorian Curriculum and Assessment Authority n.d.).

\section{Religious Diversity in Australian Media}

News media, in its collective sense encompassing print, broadcast, digital and social formats, is increasingly viewed as one of the central cultural sites where religious meanings and symbols inform public imaginations of religions (Hoover 2002, 2011). Australian research reflects this, where news media remain a primary source of information about Muslims for non-Muslims, and has played a role in perpetuating negative stereotypes of, and fear of, Muslims and Islam (Bouma et al. 2007; Dunn et al. 2007; Rane et al. 2014; O'Donnell et al. 2018). The mediatisation of religion theory informs this, as news media becomes instrumental in determining and defining religious meanings, practices and symbols for a wider public (Hjarvard 2011, 2013; Lövheim 2014). News reporting about religions has become an area of scholarly concern, since journalists still maintain a critical role in the selection of information and reporting of news events, even though news media industries are in a state of crisis and decline (Deuze and Witschge 2020; Zion et al. 2016). News media reporting is no longer confined to print materials, but has the potential for greater dissemination locally and transnationally, through digitisation processes and a much more participatory media culture (Lewis 2012; Hujanen 2016). Moreover, as Australia continues to become less religious, understandings of religions and religious groups will be derived increasingly from news reporting (Lundby et al. 2018).

It is therefore important to further interrogate the way that Australian media represents religion and religious diversity, including spirituality and non-religion, beyond studies of media and religion that have, in recent years, often focused largely on Islam. The media also has a tendency to polarise debates about religion through its selection of information and representatives. Enqi Weng (2020), in her study of the Australian Broadcasting Corporation's popular program QEA from 2009 to 2013, found that discussions about religion were primarily represented by, and constructed using, Catholic and Atheist perspectives, and especially by white middle-class men. Islam was also a topic of interest on $Q \mathcal{E} A$, but there was far less Buddhist and Jewish representation, and no mention of Hindus or Hinduism whatsoever. More in keeping with the diversity of non-religious expressions in the Census (Bouma 2006), there was, however, some Agnostic representation, and representation of those who expressed ambiguity in their religiosity/non-religiosity. Broadly, while references to major religions were mostly neutral, they tended to be negative rather than positive when they occur. By contrast, references to non-religion were exceedingly positive, such as through the sacralisation of political parties, the environment, democracy, humanity, the economy and historical artifacts as some examples. Furthermore, through the coding of religion using a broad spectrum of categories, Weng's (2020) study's findings suggested religion's multifaceted presence in obvious and more subtle ways in Australian public life and meaning-making. A similar methodology was employed in the Religion on an Ordinary Day study. 


\section{Methods}

A mixed-methods quantitative and qualitative approach using thematic content analysis was applied to printed newspapers in Melbourne, on an ordinary day of 17 September in 2013, 2014 and 2015. Three broadsheets and tabloids that capture major demographics were selected. Three researchers (Weng, Halafoff and Horsfield) independently coded the newspapers, and compared and refined coded references after discussions. An expanded understanding of the concept of 'religion' was applied in the coding process, including Conventional Religion, Common Religion and the Secular Sacred (Knott et al. 2013). ${ }^{4}$ This framework was previously developed by Kim Knott, Elizabeth Poole and Teemu Taira for their project on 'Media Portrayals of Religions and the Secular Sacred' and slightly adapted for the Religion on an Ordinary Day project. ${ }^{5}$ Weng $(2019,2020)$ also used an adapted version of Knott et al. (2013) coding framework in her QEA study.

This broadening of 'religion' captures diverse popular interpretations of this term, but also ongoing debates among scholars about how it ought to be defined (Smith 1998). Conventional Religion refers to religions that are organised with defined sets of beliefs and practices, such as mainstream religions of Christianity, Islam, Buddhism, Judaism and Hinduism. Common Religion refers to attitudes and practices that acknowledge the presence of a higher power that can influence or intervene in quotidian life. Some examples include fairies, vampires and other supernatural beings. The Secular Sacred refers broadly to expressions of non-negotiability that are ascribed to secular objects, systems, things and people. This category is broad and encompasses Atheism, Secularism and Humanism, but also takes an amorphous approach to include religion-like expressions, such as faith in a political party, belonging to a football team, and more generally any form of sacralisation of the secular, such as a reverence for nature (Knott et al. 2013; Weng 2019, 2020). This broad and rather comprehensive view of religion also aims to capture its diverse, complex and changing forms as they appear in public life and in the media.

\section{Summary and Quantitative Analysis of the Newspapers}

The data reported below is from one national newspaper, The Australian, and two Melbourne newspapers, The Age and The Herald Sun (Table 1). The total number of articles across the three papers that included references to religion, encompassing Conventional Religion, Common Religion and the Secular Sacred, over the three-year period, was 588, with many more references to religion in Domestic News (397) than International News (122) and 69 mentions that were mixed. A total of 693 references were coded, as reflected in Table 1, over the three-year period. Religion appeared far more frequently as a Passing Reference (437) than a Main Issue (151) in articles. In terms of genres, News (177) was by far the largest category that included mentions of religion, followed by Sport (88), Features (75) and Reviews (63).

4 The 'Media Portrayals of Religions and the Secular Sacred' project was funded by the Arts and Humanities Research Council (AHRC)/Economic and Social Research Council (ESRC), as part of the 'Religion and Society' programme led by Linda Woodhead (Lancaster University).

5 The original codebook can be found in Knott et al. (2013) Media Portrayals of Religions and the Secular Sacred. 
Table 1. The number of references coded per newspaper based on the categories of religion over a three-year period from 2013 to 2015.

\begin{tabular}{ccccc}
\hline The Age & $\mathbf{2 0 1 3}$ & $\mathbf{2 0 1 4}$ & $\mathbf{2 0 1 5}$ & Total \\
\hline Conventional Religion & 34 & 37 & 44 & 115 \\
Common Religion & 21 & 35 & 47 & 103 \\
Secular Sacred & 10 & 10 & 7 & 27 \\
\hline The Australian & & & & \\
Conventional Religion & 19 & 24 & 42 & 85 \\
Common Religion & 35 & 16 & 43 & 94 \\
$\quad$ Secular Sacred & 12 & 5 & 13 & 30 \\
\hline The Herald Sun & & & & \\
Conventional Religion & 19 & 40 & 44 & 103 \\
Common Religion & 37 & 40 & 41 & 118 \\
Secular Sacred & 2 & 10 & 6 & 18 \\
Total references coded & & & $693^{6}$ \\
\hline
\end{tabular}

\subsection{The Australian}

The Australian is the largest national daily broadsheet. Its readers are mainly made up of professionals, managers, business leaders and the higher percentile of income earners in the nation. Its political viewpoint leans towards the conservative right. ${ }^{7}$ References to religion in The Australian were mainly found in News (85), Opinion (30), Features (19), and Sport (14) sections. Conventional Religion-Religion General (35), of a largely Christian nature, was the category that had the highest number of references overall. The Australian had a stronger focus on Islam than any of the other papers, with more references overall (28) and as a Main Issue (17). The Secular Sacred-Religion-Like (13) and the Secular Sacred-Mixed (7) were also frequently featured overall.

\subsection{The Age}

Within the state of Victoria, The Age is a daily newspaper based in Melbourne that predominantly covers Victorian News. In 2012, Fairfax announced massive job cuts to some of its papers, including The Age, and it subsequently reduced from a broadsheet to a compact, tabloid-sized paper in $2013^{8}$ (Zappone 2012). Whilst there is a decline in print readership, it remains popular with digital readers. The Age's viewpoints tend to be more progressive centre-left. References to religion were mainly found in News (39), Sport (38), Reviews (38), Features (19) and Advertisement (15) sections in this paper. The Age had high numbers of Conventional Religion-Religion General (61) references overall, but also as a Main Issue (10), and Islam also featured prominently overall (20) and dominated the Main Issue (11) coverage. Catholicism (17), the Secular Sacred-Other (14) and the Secular Sacred-Religion Like (7) also featured highly in this paper.

\subsection{Herald Sun}

The Herald Sun is a Melbourne tabloid newspaper on the conservative right side of the political spectrum, and is the daily tabloid newspaper with the highest circulation in Australia. References to religion were mainly found in News (53), Sport (36), Features (28) and Reviews (24) sections of this paper. The Herald Sun, similarly to The Age, had high numbers of Conventional Religion-Religion General (67) references overall, but also as a Main Issue (10), although Islam dominated the Main Issue

6 Up to three references were coded per article, as collectively a main issue or passing mention, totaling 693 mentions in 588 articles.

7 Roy Morgan Research (2013) published findings on the political leanings of all newspapers studied.

8 Fairfax Media merged with the Nine Entertainment Co. in 2018. 
(14) news coverage and had 17 mentions overall. The Herald Sun also had a high amount of coverage of Other Supernatural Beings (16).

The above can be explained, at least in part, by demographics and current affairs. As Australia is a predominantly Christian country, Conventional Religion-Religion General, of a mainly Christian nature, was the highest category across all three papers featuring mainly in News articles. The highest percentage of Christians in Australia are Catholic, and the large number of Catholicism references in The Age occurred as this paper played a significant role in exposing cases of institutional child sex abuse before the commencement of The Royal Commission into Institutional Responses to Child Sexual Abuse in 2013, and so, these issues continued to receive a large amount of attention in this newspaper. Islam, Australia's second largest religion, also received significant media attention during these years, largely as a result of the rise of Islamic State at that time. The more conservative right Australian included greater coverage of Islam than the Victorian papers. The absence of other minority faiths of Buddhism, Hinduism, and Judaism, by contrast, in terms of quantity of media attention across the three papers, needs also to be noted. References to the Secular Sacred were higher in the Australian and The Age. The greater number of references to Other Supernatural Beings in The Herald Sun may be explained by its tabloid, less high-brow nature and broader readership.

\section{Christianity}

The pervasiveness of Christianity was noted throughout the papers, which is indicative of its strong underlying influence on Australian life and culture, despite its decreasing numbers in the 2016 Census. It is also of interest to note here the prevailing political influence of Christianity in Australia, especially on the marriage equality debate and debates on religious freedom in recent years, as noted above, even though it is a secular society. Christianity also permeated all genres from News, to Entertainment, to Business, and to Sport in a range of ways. Entries on Christianity were coded to Catholicism, Protestantism, Other Christian Churches and Groups, and Religion General, in the absence of a Christian General category in the coding mechanism that was problematic.

In main national news stories and discussion relating to them, Catholic institutions received negative coverage in connection with The Royal Commission into Institutional Responses to Child Sexual Abuse, and also then-soon-to-be Prime Minster Tony Abbott's views on gender. On 17 September 2015, an editorial in The Age focused on two Royal Commission child sexual abuse reports on the Catholic Archdiocese of Melbourne, and on the Melbourne Response, which assessed cases against Catholic clergy. It described the Response as 'badly handled', as it had primarily defended the Catholic Church (The Age 2015a, p. 18). On the eve of Abbott's swearing in as Prime Minister on 17 September 2013, widespread discussion of the incoming Coalition government occurred in the Opinion, Letters and Reader Response sections of The Age. An opinion piece in The Age, which critiqued the lack of women on Abbott's frontbench, described Abbott as 'a man with an outlook so conservative it could only have been spawned from the Catholicism he held so dear' (Ford 2013, p. 17). A reader response in The Age included the pun, '[u]nless you are a Bishop, women don't make it into the Coalition,' as Julie Bishop was the only woman entrusted with a ministerial portfolio in the Abbott government (The Age 2013a, p. 15). Another reader in The Herald Sun questioned: 'Is Australia on the verge of becoming a theocracy? We have an Abbott as PM and a Bishop as Speaker of the House' (Harris 2013). In the same vein, the Australian Christian Lobby was also referenced negatively; Greens Senator, Sarah Hanson-Young, called for Abbott to cease 'bowing to pressure' from the Australian Christian Lobby and to instead listen to the 'overwhelming support' for marriage equality in The Australian (Karvelas 2013, p. 5).

References to the Anglican Church and other institutions in relation to The Royal Commission into Institutional Responses to Child Sexual Abuse were similarly negative. For example, the 17 September 2013 coverage noted that many religious organisations would be investigated, including the Anglican Church, Catholic Church, the YMCA and Salvation Army (Box 2013, p. 3; Zwartz 2013, p. 3). Another article in The Herald Sun mentioned a case reported to the Royal Commission on child sexual abuse 
alleged to have occurred at the Church of England Boys Society church camp (Michelburough 2015, p. 16). In contrast, when passing references were made to Anglicans and Protestants, they tended to be largely positive or neutral. The Australian quoted the Anglican Archbishop of Sydney, Glenn Davies, as having urged Abbott, 'as a Christian leader', to restore the refugee quota to 20,000 a year, to protect Iraqi Christians (Owens 2014, p. 6).

A blending of Christian and Secular Sacred-Religion-Like references was noted in the leadership spill of 2015. This occurred when Malcolm Turnbull became the Australian Prime Minister on 14 September 2015, ousting Abbott. Much of the 17 September 2015 national coverage on religion focused on this issue. An article in The Australian referred to Abbott's treasurer Joe Hockey's 'spirited defence' of his economic record (Uren 2015, p. 6), and another described the spill as a 'ritual culling of a prime minister' (Gluyas 2015, p. 23). A letter stated that Abbott was 'sacrificed on an altar of hubris', and another that he was 'crucified' (The Australian 2015a, p. 13). An opinion piece in The Age also noted that Victorians, neglected by Abbott and 'hoping for a messiah' in Turnbull, would be disappointed (Gordon 2015, p. 20).

Christianity's presence in schools largely received negative responses, especially in terms of religious instruction. A piece titled 'Religion out of favour' described how $63 \%$ of Victorian parents opposed Christian religious instruction where 'fundamentalists' were believed to be teaching children 'superstitious nonsense' and' illogical drivel' not appropriate for a 'secular setting' (Kelly 2014, p. 19). A similar reference to some Christian groups as deviant could also be seen from an article in The Herald Sun titled 'Floods hit Sect', which stated that at least 16 members of a 'polygamist Mormon sect,' the 'Fundamentalist Church of Jesus Christ of Latter-Day Saints', had been killed in floods on the Utah-Arizona border (Herald Sun 2015, p. 28).

Christianity and Christian terms also came up frequently in place names and football team names, in Arts/Entertainment, Puzzles, Business and Sport more generally. For example, notable football clubs are called The Saints and The Demons, and referred to across the three papers. Catholic references also appeared in relation to art and entertainment, such as Francis Bacon's paintings of 'screaming, diabolical popes' (Westwood 2013, p. 16), a quiz question on who is featured in the Pieta (The Australian 2013, p. 18), and a review of the silent film The Cathedral Builder (about a Catholic church in Prague) (The Age 2013c, p. 22).

Across the three-year study, references to Christianity were mixed, with negative, neutral and positive treatments. Moreover, many Christian references were humorous, of a distinctly Australian laconic nature, which suggests a level of ease with this subject, and a sense of irreverence, as people felt free to make fun of it.

\section{Conventional Religion-Minority-Faiths and New Religious Movements}

\subsection{Islam and Judaism}

Of the so-called minority faiths in Australia, Islam received the greatest attention, which was largely in discussion of international news events focused on concerns of the conflict in Syria and the rise of the Islamic State (IS), and controversies over Mosque building on the Gold Coast and Bendigo. In most of these articles, Islam was negatively associated with terrorism, although concerns about conflict and war were raised for both Muslims and non-Muslims.

The major global stories on 17 September 2013, focused on The United Nations report on the Mission to Investigate Allegations of the Use of Chemical Weapons in the Syrian Arab Republic in Ghouta on 21 August 2013. These included references in The Age to the sectarian divide between the Sunni majority and Shia minority in Syria (Zankin 2013, p. 14). The Australian also described how two senior female police officers had recently been killed in Helmand Province, a 'hotbed of Islamist insurgency' in Afghanistan (AFP 2013, p. 10).

Major global coverage on Islam increased dramatically on 17 September 2014, as the horrific video of the beheading of British aid worker and Islamic State (IS) hostage David Haines had been released 
on 14 September and representatives of 30 countries met in Paris to discuss a global strategy against IS on 15 September. Articles discussed what role the Arab states would play in the 'war against Islamic State' (Lyons 2014, p. 6), the recent US airstrikes on IS (McGeough 2014, p. 6), and the Paris talks (Stewart 2014, p. 9). Then Prime Minister Abbott was quick to pledge military support to the US and this also generated substantive debate in Australia (Kenny 2014, p. 6; Stewart 2014, p. 1).

A combination of keywords and images were used in these media reports, to either present or signal violence associated with extremist manifestations of Islam. An article in The Herald Sun, titled 'Top guns blitz evil death cult', was accompanied by photographs of Kurdish men and women in battle (Whinnett 2014, p. 7). Other photographs on the day showed four female Iranian members of the Freedom Party of Kurdistan in The Australian (Stewart 2014, p. 9), a large picture of two fighter jets in The Age (McGeough 2014, pp. 6-7), and a masked IS figure holding an IS flag, with fighter planes superimposed over a map marking US strikes in the IS-held territory in The Herald Sun (Hurley 2014, p. 6). The Australian also featured pieces on a 'Kiwi "jihadi"' (Schliebs 2014, p. 6), on Indonesia's Jaamah Ansharat Tauhid, and on Indonesians fighting in Syria and Iraq with the al-Nusra Front (Alford 2014, p. 9), and on Fiji's upcoming election and fears of 'Islamification' (Callick 2014, p. 11).

On 17 September 2014, regional news was centred on countering terrorism and protests against a mosque building. An article in The Australian described how Victoria Police would be given new 'counter-terrorism spying powers' to protect against IS inspired attacks (Ferguson 2014, p. 6). Another story, on a plan to build a Mosque on Queensland's Gold Coast, explained how, despite the fact that the area was home to over 10,000 Muslims, and thousands of tourists had visited from Arab states, the plan was rejected in a bid to contain social tensions (McKenna 2014, p. 6). Another major regional story in The Herald Sun focused on anti-mosque protestors abusing councillors who supported a new mosque being built in the Victorian country town of Bendigo. It also described how anti-Islam and anti-racism activists had clashed there over the issue (Minear 2015, p. 2). The Australian and Herald Sun used descriptors in news stories that were more sensational and fear mongering in relation to Islam. However, their coverage was not entirely negative, as there were at least attempts to engage with more 'moderate' Muslims and genuine concerns raised in relation to war and conflict in the Middle East, and the resulting refugee crisis.

Judaism similarly received negative main story coverage; in this case, associated with the sexual abuse of children. A major story reported in all three major papers on 17 September 2015, was that of a sexual abuse scandal at an ultra-orthodox Jewish school in Melbourne, where a former student was awarded one million dollars in damages (Hatch 2015, p. 12). The Australian quoted the Judge as saying the 'headmistress offender was "“evil"' (Towers 2015, p. 5) and The Herald Sun quoted the Judge as saying the headmistress was '“monstrous"' (Deery 2015, p. 2). In contrast, other references to Judaism mentioned the horrors of the holocaust, evoking outrage and compassion (Newman 2015, p. 21).

A more light-hearted, and at times humorous, treatment of Islam and Judaism occurred in Features, Entertainment and Sport. A sport article applied the Jewish term 'exodus' to describe a footballer's exit after an illegal drugs incident (Niall 2015, p. 50). The Muslim term 'mecca' was also used in reference to Adelaide as 'a wannabe mecca for budding start-ups' (Foo 2013). The Age's Green Guide (a weekly television guide) described how Ainsley Harriot's Street Food (a television program) visited Fes, Morocco in the lead up to the Eid celebration and had 'a joyful time' in 'the Muslim world' (Galvin 2015, p. 15). A documentary series on marriage described in The Age also included a Muslim couple (Farrer 2015, p. 14).

\subsection{Buddhism, Hinduism, Sikhism and Other Religions}

Non-Abrahamic religions received far less attention across the three papers and in major stories. Only one article in The Age on international trade relations between Australia and China made a passing reference to how they might be adversely affected by the Prime Minister Abbott's relations with Tibet and the Dalai Lama (White 2013, p. 17). 
Buddhism and Hinduism were largely mentioned in passing, neutrally or positively, in Opinion, Education and Puzzles. Interestingly, these references were sometimes made alongside references to the Abrahamic traditions. For example, a letter in The Australian stated: 'To set the record straight, the religion of peace is actually Buddhism ... Islam and Christianity are what they are' (The Australian 2014a, p. 13). An advertisement for a poster of World Religions in The Herald Sun featured an Indian holy man (Herald Sun 2013b, p. 45). A crossword puzzle in the same paper had 'Yoga master' as a clue, alongside 'Prayer ending,' and 'Follower of Islam' (Herald Sun 2014b, p. 60).

There were also many distinct references to Buddhist and Hindu terms and practices, in particular in Letters, Reviews, Arts, Entertainment, Travel, and Fitness. For instance, the Headspace meditation app, co-developed by a former Buddhist monk, received a positive review for training the mind 'for a healthier, happier, more enjoyable life' (Karena 2015, p. 13). An ad for a 'Railway Adventure in Myanmar', in The Australian, featured a picture of air balloons over Buddhist temples (The Australian 2015c, p. 34), while a crossword in The Australian included the clue 'Hindu garment', and a quiz clue mentioned Mahatma Gandhi (The Australian 2015d, p. 18). There was only one passing reference to a 'Sikh in a turban', in an article in The Australian on The Beatles' experimental music videos (The Australian 2015b, p. 14).

Interestingly, Buddhist, and Hindu terms have also made their way into the Australian vocabulary, with no direct reference to these religions as such. A fashion article in The Australian referred to a 'design mantra' and the 'yin and yang of things' (Traill-Nash 2014, p. 16) and Phelim McDermott as the 'guru of British theatre company Improbable' (Buzacott 2014, p. 14). A reader of The Herald Sun also exclaimed: 'I hope that karma comes back to the person that stole my yucca [plant]' (Herald Sun 2014c, p. 23).

New Religious Movements and other less mainstream religious groups received even less coverage. A Herald Sun crossword puzzle included 'Pagan' as a clue (Herald Sun 2014b, p. 60), and a quiz had a question on Scientology: 'Celebrity Centres are a feature of which religion?' (Herald Sun 2014b, p. 60). The Satanic Temple, a Satanist group in Florida, was also reported as wanting to distribute literature at schools, after Christian evangelical and Atheist groups had done so (Herald Sun 2014d, p. 27).

\section{Common Religion}

The vast majority of Common Religion entries relating to supernatural beings, witches, magic, ghosts, fairies, vampires and mythology were positive, and some had a humorous tone. Their prevalence indicates that in particular, the world of entertainment in Australia is highly enchanted. The prevalence of these entries in Entertainment, Crosswords, Cartoons, Fashion and Sport also shows a level of ease with the supernatural among Victorians, as common religion permeates everyday life. The Herald Sun also had daily sections dedicated to horoscopes and astrology.

Witches, wizards, and magic especially received a large amount of attention. Notable examples were: references to The Footy Show's Wizard of Oz photoshoot, discussed in major news above; 'Hogwarts school of magic' (Herald Sun 2013a, p. 18); and the TV Series The Witches of East End (Devlyn 2014, p. 32). Mentions of ghosts occurred less frequently, and included the Melbourne Theatre Company's upcoming production of Henrik Ibsen's The Ghosts (Harford 2013, p. 30) and the movie Ghostbusters (Johnson 2015, p. 53). There were also many references to vampires, such as an opinion piece in The Herald Sun focused on a discussion of gender in Twilight, Buffy the Vampire Slayer, and Dark Angel (Clarke 2013, pp. 20-21).

Fairy tales and fairies also received much attention. Examples included a piece titled 'Frolic with the fairies' in Tinker Bell Fairy Garden at the Royal Melbourne Show, accompanied by a large picture of a young girl wearing fairy wings (Herald Sun 2014a, p. 13), and reviews and features on the Australian Ballet's Cinderella (Dunn 2013, p. 30). Many other supernatural beings and themes were mentioned across the papers, including yetis (Northover 2013, p. 18), zombies (Squires 2013, p. 31) and superheroes, superpowers and teleportation (Blundell 2015, p. 11). 
The Herald Sun had significantly more references to Common Religion as compared to the other two newspapers. These news stories focused on spirituality, supernatural themes, healing and resilience. For example, a news story titled 'Ada's tribute to her lost angel' described an actress' resilience after the death of her stillborn son (Sams 2014, p. 3). Another article, about singer Mark Holden's cancer treatment, quoted him saying 'we're living in an age of miracles' (Dennehy 2015, p. 20), and stem cells were described in The Australian as having 'almost miraculous powers' (Baxendale 2013, p. 3).

\section{Secular Sacred}

Secular Sacred references, though not frequent, tended to be positive, reflecting extra special qualities of people, places and things. Religion-Like expressions were used to articulate this, often alongside religious ones, hence the relatively large number of Mixed entries. References to the Secular Sacred were often applied in passing in News, Business, Sports, Entertainment, Review and Opinion pieces, and were coded largely to Religion-Like, Humanism, Spirituality, Mixed and Other. Non-religious people and things were often elevated to the other-worldly. Notable examples included Barack Obama being referred to as a 'political messiah' (Montgomerie 2013, p. 13), a wine and food festival labelled a 'Shiraz Heaven' (The Age 2013d, p. 14), bacon also achieved 'divine' status (The Age 2013b, p. 6), and sport was described as being 'too sacred in our culture'. (Baum 2013, pp. 42-44). Other articles and reviews tackled Secular Sacred 'big moments' in life, which included 'life, death and the mundane' (The Age 2015b, p. 31). One school had also introduced a Philosophy Club to broaden students' critical thinking capacities (Hosking 2014, p. 12).

Expressions of non-religiosity being imbued with sacred qualities traditionally attributed to religion may reflect a time of transition from a more to a less religious society. Conversely, it may be that there are elements that have always been deemed sacred beyond and 'beneath religion' (Halafoff 2017), such as nature, human dignity and, in the Australian context, football. For instance, the Secular Sacred was also located in references to places and landscapes. One article in The Australian mentioned how the 'Balinese idea of sacredness' was found in 'landscape, animals and trees', and especially the banyan tree, because of its 'spiritual significance' (James 2015, p. 15). A tour to the sacred memorial site of the Gallipoli landings, to mark their 100th anniversary, was also advertised in The Australian (2014b, p. 28).

The relatively large number of Spirituality and Humanism mentions can be explained, as Australians widely identify as spiritual and engage in spiritual practices, as noted above, and due to the rise in those declaring no-religion. Humanism has been acknowledged recently as one of Victoria's main worldviews, alongside major religions of Christianity, Islam, Buddhism, Hinduism and Judaism (Victorian Curriculum and Assessment Authority n.d.).

\section{Discussion and Conclusions}

This study of Religion on an Ordinary Day in Melbourne, Australia revealed a prevalence of religion, spirituality and the secular sacred in its myriad forms across its newspapers. All the Abrahamic religions-Christianity, Islam and Judaism-were highly represented in news stories on conflict and controversy, such as those related to sexual abuse, terrorism and violence. Media portrayals of religion, especially in the front and priority pages of these newspapers, were primarily focused on these religions and reported through limited news frames, with an emphasis on sensationalism (Weng 2019, 2020; Zwartz 2016). Islam was negatively associated with terrorism. Catholicism, in particular, received significant negative media coverage in relation to the Royal Commission into Institutional Responses to Child Sexual Abuse, but the Anglican Church, the YMCA, the Salvation Army and a Jewish school also featured in reporting of child sexual abuse. Issues around conservative religious views on gender and religious instruction in schools equally received negative coverage.

The three Abrahamic faiths certainly had a higher level of coverage, and thereby status, than other religions, evident in the amount and prominence of attention they received. This was also reflected in the telling daily Faith section in The Age, which includes Muslim prayer times above a 'Text for the 
day' from the Old or New Testament. This demonstrates the centrality of the three major Abrahamic traditions in Australia, despite the fact that there are also a substantial number of Buddhists in Australia, and that Buddhism has a long history in this country. Buddhism, Hinduism, Sikhism, Other World Religions and New Religious Movements had significantly less media coverage, and thereby reflect less status. Similarly, media representations of these religions were either absent or minimal in current affairs discussions, further suggesting that sociopolitical discourses are dominantly informed by certain perspectives over others (Weng 2020). Sometimes, what is missing is also revealing.

Religion General references, which were mostly Christian in nature, were also located in categories beyond news, that include entertainment, business and sports. The tone of this coverage was mixed; while news references were largely negative and related to crime and murder, positive and neutral references to Christianity came up frequently in place names, football team names, in the arts, in quizzes and crosswords and sport. These Christian references were often applied in a witty or humorous way that suggests some level of familiarity with the religion, and an irreverent attitude towards it.

The pervasiveness of Christian references throughout the papers suggests its continued influence in Australian public life and culture, whether in politics, or more generally in everyday meaning-making. The presence of these references in mixed tones, however, does suggest perhaps a questioning and turning away from the authority of mainstream Christianity, and from the abuse of power that it is associated with. These findings were similarly reported in Weng's research (2020), where Catholic representatives, especially, were challenged on several sociopolitical issues and their religious input was frequently delegitimised. Yet, at the same time, these findings suggest that religion, and Christianity in particular, plays a more pervasive role in the Australian public mind in an everyday way than is often acknowledged in this supposedly secular society. Christianity was literally all over the three main papers.

Islam had a significant place in news stories, mostly through international news events, with a particular focus on the conflict in Syria and the rise of the Islamic State. Islam remains strongly and negatively associated with terrorism and violence, with mentions of IS. Domestically, news stories addressed controversies over the visibility of Islam through protests over mosque building on the Gold Coast and Bendigo. The Australian and Herald Sun especially used descriptors in news stories that were more negative and sensational in relation to Islam, yet at times, they attempted to present more 'moderate' positions and an empathetic approach to war and conflict in the Middle East, and the resulting refugee crisis.

The difference in treatment of Islam in the news is dependent on the newspaper; the medium remains integral in shaping news content, informed by a matrix of factors that include audience profile and political leaning (Knott et al. 2013; Weng 2020). Judaism was the least covered out of the three Abrahamic faiths, and similarly received negative main story coverage in association with the sexual abuse of children. Additional references to Judaism mentioned the horrors of the holocaust, with empathy toward the survivors.

In contrast, a more light-hearted and neutral approach to Islam was also evident in a small number of pieces in fashion, quizzes, food, and reviews, and to Judaism in food and entertainment. These examples show a level of everyday acceptance and appreciation for these cultures in Australian society, as do the use of terms 'exodus' and 'mecca' in the English and Australian vocabularies.

Buddhism, Hinduism and Yoga were mostly perceived as positive. These references largely appeared in travel pieces, and at times, displayed exoticism and orientalism. The papers also showed a level of lived engagement with these religions and philosophies, particularly evident in the way in which terms such as mantra, karma, rebirth and guru had made it into the Australian lexicon. This is not surprising, given Australia's geographical proximity to Asia, and as Buddhism is the third largest religion in Australia and Hinduism is the fastest growing. It is also possible to argue, however, that their lack of appearance in news coverage and their frequent citation alongside the Abrahamic faiths may mean that they are perhaps not seen as being as well-established in Australian society as yet. 
While Conventional Religion dominated major news coverage, the prevalence of Common Religion across many other genres in the newspapers provides evidence of sustained enchantment in Australian public life. Light-hearted mentions of fairies, witches, vampires, ghosts and other supernatural beings featured prominently in entertainment, crosswords, and fashion. Expressions of mundane and sometimes passing references to luck, chance and magic were embedded in sports, reader responses, letters, stories and entertainment. Supernatural forces seem also to be a source of comfort in times of need, and associated with healing, much more so than Conventional Religion. Compared to Conventional Religion, however, the presence of Common Religion is subtler and more embedded; The Australian also contained far fewer of these Common Religion entries; The Herald Sun had more references to Common Religion comparatively, perhaps because of its audience demographics.

The presence of Secular Sacred references, while much less frequent in numbers, generally tended to be positive, and referred to a quality of specialness attached to objects, people, places and systems. Their presence signals a shift of media perceptions of public attitudes towards the sacred, where secular forms of the sacred are perhaps more socially acceptable or preferred over religious sacred forms. Secular sacred references were frequently located beyond and beneath religion and referred to things and values such as nature, human dignity, democracy and football in the Australian context. It is interesting to note that the current Prime Minister Scott Morrison named ANZAC Day as Australia's 'most sacred day' as a unifying message to all Australians during the COVID-19 pandemic (Prime Minister of Australia 2020).

This shift in the sacralisation from religious to secular forms is most evidently located in Religion-Like expressions. They tend to draw significantly from Christian references, which suggests that, while religion may not so often take centre stage, as it were, there is a pervasive but somewhat 'hidden religiosity' and particularly 'hidden Christianity' that this study has revealed, that permeates many elements of Australian life and culture. We argue that this has been previously under-acknowledged, and that this data and the analysis of it may help to explain the prevailing influence that religious groups, and especially Christian groups, have on social and political issues, such as marriage equality, religious instruction in schools, and religious freedom in Australian public life. It may also contribute further evidence of why Australian teens have such a broad but shallow level of religious literacy, given the prevalence of Conventional Religion, Common Religion and the Secular Sacred across the media and the sensationalisation of coverage, particularly of Islam and Christianity, alongside the lack of in-depth content on religion in Australia's education systems. This further strengthens the case for the need of more religious literacy programs for journalists and in schools, to develop a better understanding of Australia's lived and complex worldview diversity.

Author Contributions: Investigation, E.W. and A.H.; Writing-original draft, E.W. and A.H.; Writing-review \& editing, E.W. and A.H. All authors have read and agreed to the published version of the manuscript.

Funding: The authors, and their collaborator in the project's earlier stages Peter Horsfield, did not receive any external grant funding to work on the Melbourne case study for the 'Religion on an Ordinary Day' project. They did receive travel funding from the UK's Economic and Social Research Council's 'Religion, Discourse and Diversity Project,' and the Canadian Social Sciences and Humanities Research Council's 'Religion and Diversity Project' to attend two workshops, in London (Halafoff and Horsfield) and Ottawa (Halafoff and Weng), as part of the 'Religion on an Ordinary Day' team to develop the framework of the project and report on its findings.

Conflicts of Interest: The authors declare no conflict of interest.

\section{References}

AFP. 2013. Second Woman Top Cop Shot Dead. The Australian, September 17, p. 10. Alford, Peter. 2014. Bashir's Terror Call Sparks Exodus to Syrian Rival. The Australian, September 17, p. 9. Baum, Greg. 2013. Bytes and Bets Transform a Backwater into Behemoth. The Age, September 17, p. 42. Baxendale, Rachel. 2013. Stem Cell 'Miracle' Lifts Hope on Stroke. The Australian, September 17, p. 3. Blundell, Graeme. 2015. That Painful Leap from Obscurity to Superhero. The Australian, September 17, p. 17. Bouma, Gary D. 2006. Australian Soul: Religion and Spirituality in the 21st Century. Melbourne: Cambridge University Press. 
Bouma, Gary D., and Anna Halafoff. 2017. Australia's Changing Religious Profile-Rising Nones and Pentecostals, Declining British Protestants in Superdiversity: Views from the 2016 Census. Journal for the Academic Study of Religion 30: 129-43. [CrossRef]

Bouma, Gary D., Sharon Pickering, Hass Dellal, and Anna Halafoff. 2007. Managing the Impact of Global Crisis Events on Community Relations in Multicultural Australia. Queensland: Multicultural Affairs Queensland and the Victorian Office of Multicultural Affairs.

Box, Dan. 2013. Scouts Abuse Whistleblower Applauded. The Australian, September 17, p. 3.

Buzacott, Martin. 2014. It's a Small World after All. The Australian, September 17, p. 14.

Callick, Rowan. 2014. Fiji Holds Its Breath to Vote. The Australian, September 17, p. 11.

Clarke, Alice. 2013. Whiny Bella Sends Strong Women into the Twilight. Herald Sun, September 17, p. 20.

Deery, Shannon. 2015. \$1m School Abuse Cash. Herald Sun, September 17, p. 2.

Dennehy, Luke. 2015. Holden's Cancer Struggle. Herald Sun, September 17, p. 20.

Deuze, Mark, and Tamara Witschge. 2020. Beyond Journalism. Cambridge: Polity.

Devlyn, Darren. 2014. Madchen Casts a Horror TV Spell. Herald Sun, September 17, p. 32.

Dunn, Amanda. 2013. Her Coach Gone, Cinderella Takes a Step to the Stars. The Age, September 17, p. 30.

Dunn, Kevin M., Natascha Klocker, and Tanya Salabay. 2007. Contemporary racism and Islamaphobia in Australia Racializing religion. Ethnicities 7: 564-89. [CrossRef]

Ezzy, Douglas, Gary Bouma, Greg Barton, Anna Halafoff, Rebecca Banham, Robert Jackson, and Lori Beaman. 2020. Religious Diversity in Australia: Rethinking social cohesion. Religions 11: 92. [CrossRef]

Farrer, Gordon. 2015. Sunday, September 20. The Age, September 17, p. 14.

Ferguson, John. 2014. State Police Win Beefed-up Terror Laws. The Australian, September 17, p. 6.

Foo, Fran. 2013. Sketches for Some Blissfully Bold Ideas. The Australian, September 17, p. 31.

Ford, Clementine. 2013. Cabinet Cast List Reveals an Archaic View of Women. The Age, September 17, p.17.

Furseth, Inger. 2018. Secularization, Deprivatization, or Religious Complexity. In Religious Complexity in the Public Sphere: Comparing Nordic Countries. Edited by Inger Furseth. Cham: Palgrave, pp. 291-312.

Galvin, Nick. 2015. Thursday, September 24. The Age, September 17, p. 15.

Gluyas, Richard. 2015. Aside the Political Chaos, Murray Review a Textbook Case of Reform. The Australian, September 17, p. 23.

Gordon, Josh. 2015. On the Roads Again, but Will Cash Finally Flow? The Age, September 17, p. 20.

Halafoff, Anna. 2017. Beneath Religion: Whale watching and the More-than-human turn in Sociology of Religion. Paper presented at the Development for Species: Animals in Society, Animals as Society' Conference, Deakin University, Melbourne, Australia, September 18-19.

Halafoff, Anna, Lam Kim, and Gary Bouma. 2019a. Worldviews Education: Cosmopolitan Peacebuilding and Preventing Violent Extremism. Journal of Beliefs and Values. 40: 381-95. [CrossRef]

Halafoff, Anna, Andrew Singleton, Gary Bouma, and Mary Lou Rasmussen. 2019b. Religious Literacy of Australia's Gen Z Teens: Diversity and Social Inclusion. Journal of Beliefs and Values. 41: 195-213. [CrossRef]

Halafoff, Anna, Heather Shipley, Pamela D. Young, Andrew Singleton, Mary Lou Rasmussen, and Gary Bouma. 2020. Complex, Critical and Caring: Young people, worldviews and diversity in Australia and Canada. Religions 11: 166. [CrossRef]

Harford, Sonia. 2013. Dog Days in Diverse Mtc Season. The Age, September 17, p. 30.

Harris, John. 2013. 50/50—Letter from John Harris. Herald Sun, September 17, p. 18.

Hatch, Patrick. 2015. School to Pay \$1m to Abuse Survivor. The Age, September 17, p. 12.

Herald Sun. 2013a. Gluttonous Is the Word. Herald Sun, September 17, p. 18.

Herald Sun. 2013b. World Religions. Herald Sun, September 17, p. 45.

Herald Sun. 2014a. Frolic with Fairies. Herald Sun, September 17, p. 13.

Herald Sun. 2014b. Quizmaster. Herald Sun, September 17, p. 60.

Herald Sun. 2014c. Text Talk. Herald Sun, September 17, p. 23.

Herald Sun. 2014d. Weird World. Herald Sun, September 17, p. 27.

Herald Sun. 2015. Deadly Floods Hit Sect. Herald Sun, September 17, p. 28.

Hjarvard, Stig. 2011. The Mediatisation of Religion: Theorising Religion, Media and Social Change. Culture and Religion: An Interdisciplinary Journal 12: 119-35. [CrossRef]

Hjarvard, Stig. 2013. The Mediatization of Culture and Society. New York: Routledge.

Hjelm, Titus. 2015. Is God Back?: Reconsidering the New Visibility of Religion. London: Bloomsbury. 
Hoover, Stewart M. 2002. The Culturalist Turn in Scholarship on Media and Religion. Journal of Media E Religion 1: 25 .

Hoover, Stewart M. 2011. Media and the Imagination of Religion in Contemporary Global Culture. European Journal of Cultural Studies 14: 610-25. [CrossRef]

Hosking, William. 2014. Thinking Becomes Class Act. Herald Sun, September 17, p. 12.

Hujanen, Jaana. 2016. Participation and the blurring values of journalism. Journalism Studies 17: 871-80. [CrossRef]

Hurley, David. 2014. Travellers Cop a Grilling. Herald Sun, September 17, p. 6.

.idcommunity. n.d. Victoria, Religion. Available online: https://profile.id.com.au/australia/religion?WebID=110 (accessed on 10 May 2020).

James, Rodney. 2015. Bali High: Intoxicated by the Image of an Enchanted Isle. The Australian, September 17, p. 15.

Johnson, Neala. 2015. Foxtel. Herald Sun, September 17, p. 53.

Karena, Cynthia. 2015. An App for Introspection. The Age, September 17, p. 13.

Karvelas, Patricia. 2013. Don't Let Pm Veto Gay Bill. The Australian, September 17, p. 5.

Kelly, Jen. 2014. Religion out of Favour. Herald Sun, September 17, p. 19.

Kenny, Mark. 2014. We Don't Need Un Nod to Fight: Abbott. The Age, September 17, p. 6.

Knott, Kim, Elizabeth Poole, and Teemu Taira. 2013. Media Portrayals of Religion and the Secular Sacred. Surrey: Ashgate.

Lewis, Seth C. 2012. The tension between professional control and open participation: Journalism and its boundaries. Information, Communication $\mathcal{E}$ Society 15: 836-66.

Lövheim, Mia. 2014. Mediatization and Religion. In Mediatization of Communication. Edited by Knut Lundby. Berlin and Boston: Mouton de Gruyter, pp. 547-71.

Lundby, Knut, Henrik Reintoft Christensen, Ann Kristin Gresaker, Mia Lövheim, Kati Niemelä, Sofia Sjö, Marcus Moberg, and Árni Svanur Daníelsson. 2018. Religion and the Media: Continuity, Complexity, and Mediatization. In Religious Complexity in the Public Sphere. Edited by I. Furseth. Cham: Springer, pp. 193-249.

Lyons, John. 2014. 'Mowing the Lawn' Will Fail to Cut Down Islamic State. The Australian, September 17, p. 6.

Markus, Andrew. 2017. Mapping Social Cohesion: The Scanlon Foundation Surveys 2017. Melbourne: Monash University.

McGeough, Paul. 2014. Obama Makes a Point with Deep Strike. The Age, September 17, p. 6.

McGuire, Meredith. 2008. Lived Religion: Faith and Practice in Everyday Life. New York: Oxford University Press.

McKenna, Michael. 2014. Mosque Plan Defeated over Protest Fears. The Australian, September 17, p. 6.

Michelburough, Peter. 2015. Law Toying with Kids. Herald Sun, September 17, p. 16.

Minear, Tom. 2015. Mayor Flees Mosque Protests. Herald Sun, September 17, p. 2.

Montgomerie, Tim. 2013. United Shakes of America. The Australian, September 17, p. 11.

Newman, Louise. 2015. Now for a Rethink on Our Response to Refugees. The Age, September 17, p. 21.

Niall, Jake. 2015. Tigers Look at Options on Bennell. The Age, September 17, p. 50.

Northover, Kylie. 2013. Martin, Set to Unleash Yeti, Hopes It's Not Abominable. The Age, September 17, p. 18.

O'Donnell, Kate, Jacqui Ewart, and Shannon Walding. 2018. Perceptions and Realities: The Main Sources of Information for Non-Muslim Australians About the Religion of Islam and Muslim People. Journalism 1-17. [CrossRef]

Owens, Jared. 2014. Pm Urged to Lift Refugee Intake. The Australian, September 17, p. 6.

Pepper, Miriam, and Ruth Powell. 2016. Australian Community Survey (2016 ACS). Sydney: NCLS Research.

Prime Minister of Australia. 2020. Address-Anzac Day Commemorative Service. Canberra. Available online: https://www.pm.gov.au/media/address-anzac-day-commemorative-service (accessed on 3 July 2020).

Rane, Halim, Jacqui Ewart, and John Martinkus. 2014. Media Framing of the Muslim World: Conflicts, Crises and Contexts. Basingstoke: Palgrave Macmillan.

Roy Morgan Research. 2013. The Political Profiles of Newspapers: Readership of News Corp Mastheads Skews 10\% to L-NP. Available online: http://www.roymorgan.com/findings/5136-political-profiles-of-newspapersreaderships-june-2013-201308272330 (accessed on 3 July 2020).

Sams, Christine. 2014. Ada's Tribute to Her Lost Angel. Herald Sun, September 17, p. 3.

Schliebs, Mark. 2014. Nz Silent on Fate of Kiwi 'Jihadi'. The Australian, September 17, p. 6.

Singleton, Andrew, Mary Lou Rasmussen, Anna Halafoff, and Gary D. Bouma. 2019. Australia's Generation Z Study: Australia's Teenagers Negotiating Religion, Sexuality and Diversity. Project Report. Melbourne: Deakin University. 
Smith, Jonathan Z. 1998. Religion, Religions, Religious. In Critical Terms for Religious Studies. Edited by Taylor Mark C. Chicago: University of Chicago Press, pp. 269-84.

Squires, Tony. 2013. There's More Life yet in Tales of Undead. The Age, September 17, p. 31.

Stewart, Cameron. 2014. Australia More Willing Than Waiting, as Arab States Hesitate to Commit Troops. The Australian, September 17, p. 6.

The Age. 2013a. And Another Thing. The Age, September 17, p. 15.

The Age. 2013b. The Feed This Week @Goodfood.Com.Au. The Age, September 17, p. 6.

The Age. 2013c. Live Score Brings Silent Film to Life. The Age, September 17, p. 22.

The Age. 2013d. Shiraz Heaven. The Age, September 17, p. 14.

The Age. 2015a. A National Scheme for Abuse Victims Vital. The Age, September 17, p. 18.

The Age. 2015b. Tomorrow: Life Stories. The Age, September 17, p. 31.

The Australian. 2013. Take the Challenge. The Australian, September 17, p. 18.

The Australian. 2014a. The Australian. 2014a. Letter. The Australian, September 17, p. 13.

The Australian. 2014b. Once in a Lifetime. The Australian, September 17, p. 28.

The Australian. 2015a. Commentary. The Australian, September 17, p. 13.

The Australian. 2015b. Mccartney and Starr Spruik the Beatles' 'Experimental' Videos. The Australian, September 17, p. 14.

The Australian. 2015c. Scott Mcgregor's Railway Adventures. The Australian, September 17, p. 34.

The Australian. 2015d. Take the Challenge. The Australian, September 17, p. 18.

Towers, Katherine. 2015. Orthodox Student Wins \$1m for Abuse. The Australian, September 17, p. 5.

Traill-Nash, Glynis. 2014. Practical Magic. The Australian, September 17, p. 16.

Uren, David. 2015. Feisty Hockey Comes out Swinging on His Record. The Australian, September 17, p. 6.

Victorian Curriculum and Assessment Authority. n.d. Learning about World Views and Religions. Victorian Curriculum and Assessment Authority. Available online: https://victoriancurriculum.vcaa.vic.edu.au/static/ docs/Learning\%20about\%20World\%20Views\%20and\%20Religions.pdf (accessed on 20 May 2018).

Weng, Enqi. 2020. Media Perceptions of Religious Changes in Australia: Of Dominance and Diversity. London: Routledge.

Weng, Enqi. 2019. Through a National Lens Darkly: Religion as a Spectrum. Journal for the Academic Study of Religion 32: 1-21. [CrossRef]

Westwood, Matthew. 2013. Spring, Season of Breathless Creativity. The Australian, September 17, p. 16.

Whinnett, Ellen. 2014. Top Guns Blitz Evil Death Cult. Herald Sun, September 17, p. 7.

White, Hugh. 2013. On World Stage, Abbott Faces Hard Choices. The Age, September 17, p. 17.

Zankin, Vincent. 2013. Syria. The Age, September 17, p. 14.

Zappone, Chris. 2012. Fairfax to shed 1900 staff, erect paywalls. In The Age. Melbourne: Fairfax.

Zion, Lawrie, Andrew Dodd, Merryn Sherwood, Penny O'Donnell, Timothy Marjoribanks, and Matthew Ricketson. 2016. Working for Less: The Aftermath for Journalists Made Redundant in Australia between 2012 and 2014. Communication Research and Practice 2: 117-36. [CrossRef]

Zwartz, Barney. 2013. Royal Commission on Child Sex Abuse Begins with Scouts. The Age, September 17, p. 3.

Zwartz, Barney. 2016. Religion in the Media: How Has It Changed, Where Is It Going, Why Does It Matter? ABC Religion and Ethics. August 24. Available online: http://www.abc.net.au/religion/articles/2016/08/24/ 4525572.htm (accessed on 5 September 2017).

(C) 2020 by the authors. Licensee MDPI, Basel, Switzerland. This article is an open access article distributed under the terms and conditions of the Creative Commons Attribution (CC BY) license (http://creativecommons.org/licenses/by/4.0/). 